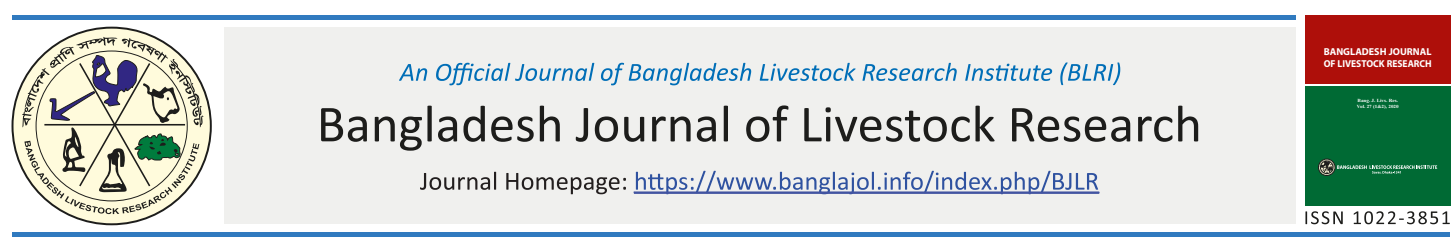

\title{
Genetic diversity analysis of lactic acid bacteria isolated from regional yogurt samples
}

\author{
K. M. Hossain ${ }^{1 *}$, B. Mazumder ${ }^{1}$, S.M.M. Rahman ${ }^{1}$ and M.A. Hamid ${ }^{2}$ \\ ${ }^{1}$ Biotechnology and Genetic Engineering Discipline, Khulna University, Khulna-9208, \\ Bangladesh \\ ${ }^{2}$ Bangladesh School of Agriculture and Rural Development, Bangladesh Open University, \\ Gazipur-1705, Bangladesh
}

\begin{abstract}
Probiotics are live, non-pathogenic microorganisms which have enormous health benefits. Yogurt is a potential source of probiotic bacteria. Lactic acid bacteria are the most common and major group of probiotic bacteria that can be found easily in different dairy products. The aim of study was the genetic diversity analysis using random amplified polymorphic DNA (RAPD) marker from regional yogurt samples of Bangladesh. Ten probiotic isolates from yogurt samples of different sweet meat shops of Sylhet and Mymensingh Divisions of Bangladesh were used. Morphological and biochemical tests were performed to ensure the presumptive probiotic characteristics of isolated bacteria. All isolates were cultured in De Man, Rogosa, and Sharpe (MRS) medium to exhort the growth of lactic acid bacteria. Genomic DNA was extracted by Ampicillin Lysozyme Tandem method. Four random RAPD primers were used in this study for detecting genetic diversity of these isolated bacteria. Among them, OPA 18 showed the maximum number of reproducible bands. Nei's genetic distance was performed for determining Pair-wise Genetic Distance. UPGMA and NJ dendrogram were performed based on molecular data showing that all the isolates could be divided into two major clusters. Data analysis revealed that isolates from the same location were closely related and showed less genetic variation whereas, isolates from geographically different regions exhibited more genetic diversity.
\end{abstract}

Key words: Lactic acid bacteria, Genetic diversity, RAPD-PCR and Yogurt samples

Bang. J. Livs. Res. Vol. 27 (1\&2), 2020: P. 55-63. $\quad$ https://doi.org/10.3329/bjlr.v27i1.55169

\section{Introduction}

The word 'probiotic' is evolved from a peculiar mix of Latin (pro means for) and
Greek (bios means life) words. The term coined in 1960 as conversed to antibiotics and defined as substances originates from

*Corresponding author: kmhossainbt@yahoo.com.au 
protozoa. Two scientists named Lilley and Stillwell first narrated the term probiotics appropriately. They described it as the substances secreted by one microorganism that has the ability to stimulate the growth of another microorganism in our digestive tract (Lilly and Stillwell, 1965). Probiotic bacteria are gut beneficial bacteria that can create a physical barrier against harmful bacteria. Presently, more people are using probiotic products in order to treat their illnesses or to keep up overall well-being. Fermented food products like yogurt is a potential source of probiotics which contains potassium, $\mathrm{B}_{2}, \mathrm{~B}_{12}$, calcium, magnesium, zinc and helps to maintain lower levels of circulating triglycerides, glucose, and lower systolic blood pressure and insulin resistance (Wang et al., 2013).

Fermented milk products, cheese, yogurt are the major sources of probiotic bacteria. Fermentation of yogurt involves basically the use of lactic acid bacteria (LAB) like $L$. acidophilus, L. rhamnosus, Lactobacillus bulgaricus, Lactobacillus plantarum, Bacillus coagulans, Bifido- bacteria spp., Pediococcus spp., Lactococcus spp., and Streptococcus spp. and so on (Bintsis , 2018, Nero et al., 2008). Lactic acid bacteria are gram-positive, acid tolerant, usually nonsporulating, either rod-shaped (bacilli) or spherical (cocci) bacteria that share common metabolic and physiological characteristics. The methods for identification of lactobacilli at the strain level are very important and also beneficial for tracing new strains, because probiotics receptivity depends on its strain (Mayer et al., 2005). Phenotypic characters (morphological and biochemical characters) of lactic acid bacteria is not appropriate to differentiate them properly. For this reason, molecular characterization based on genetic characterization is badly needed. Several molecular methods are being used for the detection of genetic polymorphism such as DNA hybridization, protein pattern analysis, random amplified polymorphic DNA (RAPD), 16s rRNA gene analysis and repetitive elements palindromic PCR (REP-PCR). RAPD and polymerase chain reaction (PCR) are widely applicable methods for the amplification of DNA that are very sensitive, inexpensive, can be used for a large number of DNA samples within a short time (Tafvizi et al., 2012). For classifying and ascertaining genetic variation and tracing lactic acid bacteria to the strain level RAPD markers have been widely applied (Samarzija et al., 2002; Kaur et al., 2016).

PCR is employed effectively for the evaluation of bacterial genetic diversity. Pair wise genetic sequence (Nei's genetic distance), unweighted pair group method with arithmetic mean (UPGMA) dendrogram are usually performed using the software PAUP (version 4.0) and NJ (Neighborjoining) dendrogram performed to study the genetic distance and similarity. The results of the present study expected to provide information regarding the genetic variation in regional yogurt samples of Sylhet and Mymensingh Divisions of Bangladesh. The detection, molecular characterization and screening of probiotic function of Lactobacillus have been conducted partly using poultry sources in Mymensingh Division of Bangladesh (Kabir et al., 2016). Literature reveals that research regarding molecular characterization of lactic acid bacteria from yogurt has not been conducted 
so far in Bangladesh. Therefore, the present research work was undertaken for DNA extraction and genetic diversity analysis of lactic acid bacteria isolated from selected regional yogurt samples of Bangladesh by using RAPD marker.

\section{Materials and Methods}

\section{Sample collection and isolation of lactic acid bacteria}

A total of 10 yogurt samples (5 samples from Sylhet and 5 samples from Mymensingh) were collected from different dairy and sweet meat shops of Sylhet and Mymensingh Division of Bangladesh using ice box. Samples were diluted 7 times in peptone solution $(0.1 \% \mathrm{w} / \mathrm{v})$ and then inoculated in selective MRS broth media ( $\mathrm{pH}$ 6.5) thereafter incubated under anaerobic conditions at $37^{\circ} \mathrm{C}$ temperature for $24 \mathrm{~h}-48 \mathrm{~h}$ in a bacteriological incubator. For the isolation of bacteria, the pour plate technique was used. Then the single colony of each sample was selected and isolated by using streak plate techniques. Probiotic properties of the isolates like low $\mathrm{pH}$ tolerance, bile tolerance, antimicrobial activity, $\mathrm{NaCl}$ tolerance, Coagulase test, Motility test, Sugar fermentation tests were performed following standard reference methods. The using of MRS (De Man, Rogosa and Sharpe) media was aimed to isolation of lactic acid bacteria.

\section{DNA extraction}

The pure colony was transferred into $5 \mathrm{ml}$ sterile MRS broth culture and incubated at $37^{0} \mathrm{C}$ temperature for $24 \mathrm{hr}$. Then $100 \mu \mathrm{l}$ of active broth culture was re-inoculated into $10 \mathrm{ml}$ sterile MRS broth and incubated at $37^{\circ} \mathrm{C}$ temperature for $10 \mathrm{~h}$. The total genomic
DNA was extracted according to De et al. (2010) with slight modification. Two $\mathrm{ml}$ of bacterial culture was taken into a $2 \mathrm{ml}$ micro-centrifuge tube and centrifuged at $5000 \mathrm{rpm}$ for $5 \mathrm{~min}$ in a refrigerated centrifuge. The pellet washed twice using 1 $\mathrm{ml}$ of Na-EDTA. Bacterial washed pellet was resuspended in $100 \mu \mathrm{l}$ of $\mathrm{NaCl}$-EDTA and $100 \mu \mathrm{l}$ of lysozyme solution was mixed. Subsequently, $4 \mu \mathrm{l}$ of RNase-A solution was added to the mixture before incubation to remove RNA. Then, the total mixture was incubated at $37^{\circ} \mathrm{C}$ temperature for $1 \mathrm{~h}$ with intermittent shaking. After that, additional $\mathrm{NaCl}$-EDTA $(430 \mu \mathrm{l})$ and $50 \mu \mathrm{l}$ of a $10 \%$ SDS solution, $10 \mu$ l of proteinase $\mathrm{K}$ solution (20 $\mathrm{mg} / \mathrm{ml}$ ) were added to the mixer to make up to $500 \mu \mathrm{l}$. The contents were mixed properly and incubated at $55^{\circ} \mathrm{C}$ temperature for $1 \mathrm{~h}$. An equal volume of Tris-saturated phenol (pH 8.0) was added after incubation and centrifuged at $10,000 \mathrm{rpm}$ at $22^{\circ} \mathrm{C}$ temperature for $10 \mathrm{~min}$ and then the upper aqueous phase was discarded carefully. This step was repeated once with a fresh aliquot of Phenol-Chloroform mixture (1:1). The supernatant was collected and 0.8 volumes of Iso-propanol in the presence of $0.5 \mathrm{M}$ Sodium Acetate $(\mathrm{pH}$ 5.2) were added to precipitate out DNA in the supernatant and re-centrifuged at $10,000 \mathrm{rpm}$ at $4^{\circ} \mathrm{C}$ temperature for $10 \mathrm{~min}$. The supernatant was discarded and the DNA pellet was washed once with freshly prepared $70 \%$ ethanol and air dried and re-suspended in $100 \mu \mathrm{l}$ TE buffer ( $\mathrm{pH}$ 8.00). DNA samples were evaluated both quantitatively and qualitatively before PCR amplification.

\section{RAPD-PCR}

RAPD-PCR was performed according to the protocol of Chao et al., (2008) with slight 
modification.). The primers used were OPA 2 (5'-TGCCGAGCTG-3'), OPA 5 (5'AGGGGTCTTG -3'), OPA-08 (5'GTGACGTAGG-3') and OPA-18 (5'-AGGTGACCGT-3'). The PCR reaction mix was created by $0.20 \mu \mathrm{l}$ of $250 \mu \mathrm{M}$ dNTPs, $0.30 \mu$ of $1.5 \mathrm{U}$ Tag DNA, $2.40 \mu \mathrm{l}$ of $3 \mathrm{mM} \mathrm{MgCl} 2,2.00 \mu \mathrm{l}$ of $1 \times$ PCR buffer, $1.00 \mu \mathrm{l}$ of 10 Pmol primer, $1.00 \mu \mathrm{l}$ of $5 \mathrm{ng} / \mu \mathrm{l}$ DNA template and $13.10 \mu \mathrm{l}$ PCR grade water for $20 \mu \mathrm{l}$ solution. Temperature profile of PCR reaction consisted of 1 cycle for initial denaturation at $94^{\circ} \mathrm{C}$ temperature for $3 \mathrm{~min}, 30$ cycles of denaturation for $2 \mathrm{~min}$ at $94^{\circ} \mathrm{C}$ temperature, primer annealing for 1 min at $370 \mathrm{C}$ temperature, primer extension for $2 \mathrm{~min}$ at $72^{\circ} \mathrm{C}$ temperature and final extension for $5 \mathrm{~min}$ at $72^{\circ} \mathrm{C}$ temperature.

\section{Agarose gel electrophoresis}

The quality of the DNA was determined by using gel electrophoresis which stained by ethidium bromide. The DNA fragments were observed under UV transilluminator after staining.

\section{Genetic diversity Analysis}

RAPD bands were treated as binary digits like if the band was presented then scored as 1 and 0 for absent, separately for each individual and each primer. The genetic similarities were calculated between all pairs of lactic acid bacteria accessions through the software Phylogenetic Analysis Using Parsimony (PAUP) version 4.0. Grouping of the genotypes were done by using UPGMA (Unweighted Paired Group with Arithmetic Average) and NJ (Neighbor-Joining) clustering methods.

\section{Results}

\section{Isolation of lactic acid bacteria}

Yogurt samples were collected from different regions of Bangladesh. At first they were separated according to their colony morphology, gram reaction and catalase reaction. Gram positive and catalase negative bacilli and cocci were elected for further biochemical tests (Table 1). MRS media was used because of the presence of Sodium Acetate, Ammonium Citrate, Magnesium Sulfate, Manganese Sulfate and Tween 80 which allow lactic acid bacteria to grow on the medium. Their morphological and biochemical characteristics also considered them as probiotic bacteria.

\section{DNA content measurement}

After DNA extraction, the genomic DNA from 10 bacterial isolates were visualized in $1.5 \%$ electrophoresis gel. Quantitative measurement of DNA was done by using UV spectrophotometer absorbance at 230 $\mathrm{nm}, 260 \mathrm{~nm}$ and $280 \mathrm{~nm}$. The readings at A260/280 ratio were within 1.5- 2.1. At $260 / 230$ ratio the results were within 1.4-2.2.

\section{RAPD analysis}

Four universal primers (OPA 2, OPA 5, OPA 8 and OPA 18) were used for producing reproducible bands. Total 131 bands were produced. Among them OPA 18 produced highest (19 bands) number of bands and lowest 2 number of bands were produced by OPA 5 (Figure 1 and Figure 2). The frequencies of polymorphic bands varied from primer to primer. OPA 2 and OPA 8 didn't generate satisfactory number of polymorphic bands. 
Table 1. Morphological and biochemical characteristics of probiotic isolates collected from Sylhet and Mymensingh Divisions

\begin{tabular}{c|c|c|c|c|c|c|c|c|c}
\hline $\begin{array}{c}\text { Yogurt } \\
\text { samples } \\
\text { Name }\end{array}$ & Shape & $\begin{array}{c}\text { Gram } \\
\text { strain }\end{array}$ & $\begin{array}{c}\text { Catalase } \\
\text { test }\end{array}$ & $\begin{array}{c}\text { Coagulation } \\
\text { test }\end{array}$ & $\mathrm{p}^{\mathrm{H}}$ test & $\begin{array}{c}\text { Bile } \\
\text { salt test }\end{array}$ & \multicolumn{3}{|c}{$\begin{array}{c}\text { NaCl } \\
\text { test }\end{array}$} \\
\hline Sy 1 & Bacilli & + & - & + & 3.0 & $0.3 \%$ & $4 \%$ & $6 \%$ & $8 \%$ \\
\hline Sy 2 & Bacilli & + & - & + & ++ & ++ & ++ & + & - \\
\hline Sy 3 & Cocci & + & - & + & ++ & ++ & ++ & + & - \\
\hline Sy 4 & Bacilli & + & - & + & ++ & ++ & ++ & + & - \\
\hline Sy 5 & Bacilli & + & - & + & ++ & ++ & ++ & + & - \\
\hline My 6 & Bacilli & + & - & + & ++ & ++ & ++ & + & - \\
\hline My 7 & Bacilli & + & - & + & ++ & ++ & ++ & + & - \\
\hline My 8 & Bacilli & + & - & + & ++ & ++ & ++ & + & - \\
\hline My 9 & Bacilli & + & - & + & ++ & ++ & ++ & + & - \\
\hline My 10 & Cocci & + & - & + & ++ & ++ & ++ & + & - \\
\hline
\end{tabular}

('++' indicates higher tolerance, ' + ' indicates medium tolerance, '-'indicates no tolerance)

Isolates from Sylhet Division (Sy 1, Sy 2, Sy 3, Sy 4 and Sy 5); Isolates from Mymensingh Division (My 6, My7, My8, My9 and My 10); M-Molecular marker (1kb DNA ladder).

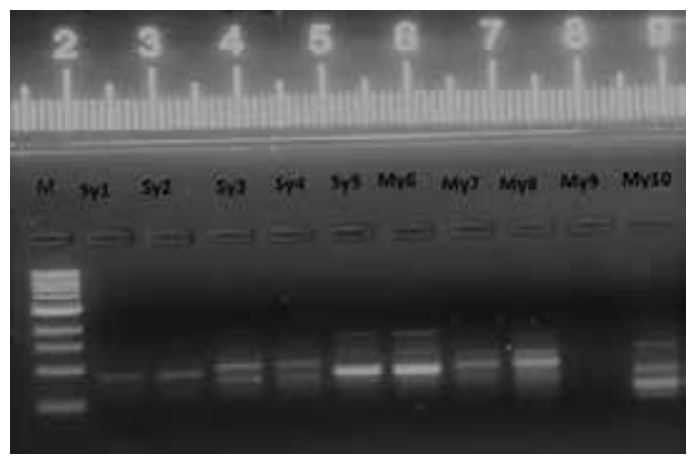

Figure 1. RAPD-PCR patterns of 10 isolates using primer OPA 18 on $1.5 \%$ agarose gel electrophoresis.

Isolates from Sylhet Division (Sy 1, Sy 2, Sy 3, Sy 4 and Sy 5); Isolates from Mymensingh Division ( My 6, My7, My8, My9 and My 10); M-Molecular marker (1kb DNA ladder).

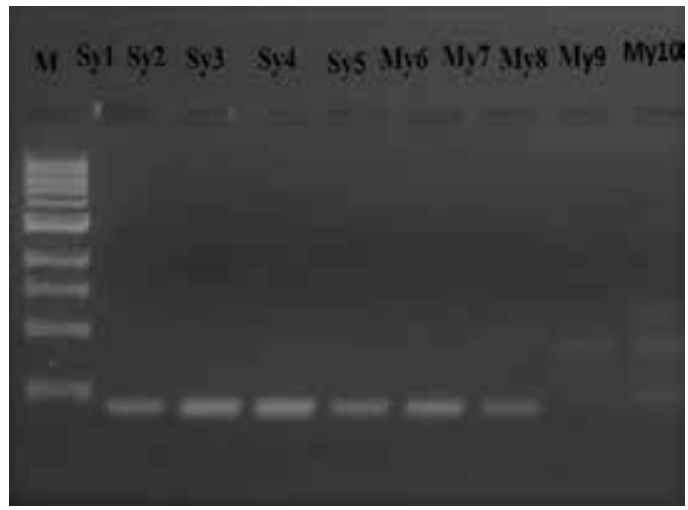

Figure 2. RAPD-PCR patterns of 10 isolates using primer OPA 5 on $1.5 \%$ agarose gel electrophoresis.

To understand the genetic relationship more clearly, Nei's genetic distance was performed. Mainly it indicates the pair wise genetic distance. Here, the measurement of genetic distance (Nei, 1972) varies between 0 and 1. ' 0 ' indicates that two populations are genetically identical (minimal or no genetic diversity). 
Whereas a value of 1 indicates two populations are genetically different (maximum genetic diversity between the two populations). The analysis showed that the genetic distance value ranged from 0.1 to 0.8 . UPGMA (Unweighted pair group method of arithmetic mean) dendrogram and NJ (Neighbor Joining) dendrogram were performed using the software PAUP version 4.0. UPGMA dendrogram divided 10 isolates into three major clusters (Figure 3). Phylogenetic analysis helped to understand the evolutionary relationship of lactic acid bacteria isolates where 'Sy' for Sylhet Division and 'My' for Mymensingh Division. Cluster I is the biggest cluster among three.

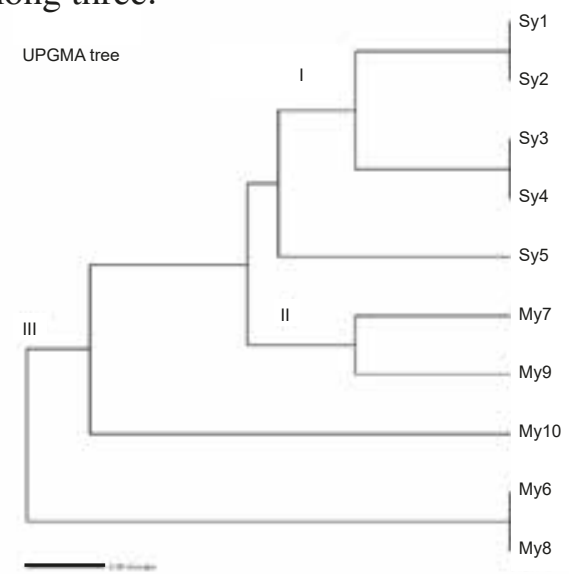

Figure 3. UPGMA dendrogram based on Nei's genetic distance, summarizing data showing dissociation of 10 isolates according to RAPD analysis.

Isolates from Sylhet Division (Sy 1, Sy 2, Sy 3, Sy 4 and Sy 5);

Isolates from Mymensingh Division (My 6, My7, My8, My9 and My 10).

The cluster I consisted of 5 Lactic acid bacteria isolates obtained from yogurt samples of different sweet meat shops of Sylhet Division. Cluster II consisted of 2 isolates and Cluster III consisted of 3 Lactic acid bacteria isolates from yogurt samples of different sweet meat shops of Mymensingh Division. This indicated that Lactic acid bacteria (LAB) isolates in clusters II and III obtained from yogurt samples of different sweet meat shops of Mymensingh Division had genetic similarities. Hence, Lactic acid bacteria isolates from yogurt samples of Sylhet Division in cluster I had different genetic diversity from LAB isolates collected from yogurt samples of Mymensingh Division. NJ clustering method performed on molecular data produced similar results like UPGMA dendrogram (Figure 4). Three main clusters were observed in NJ dendrogram.

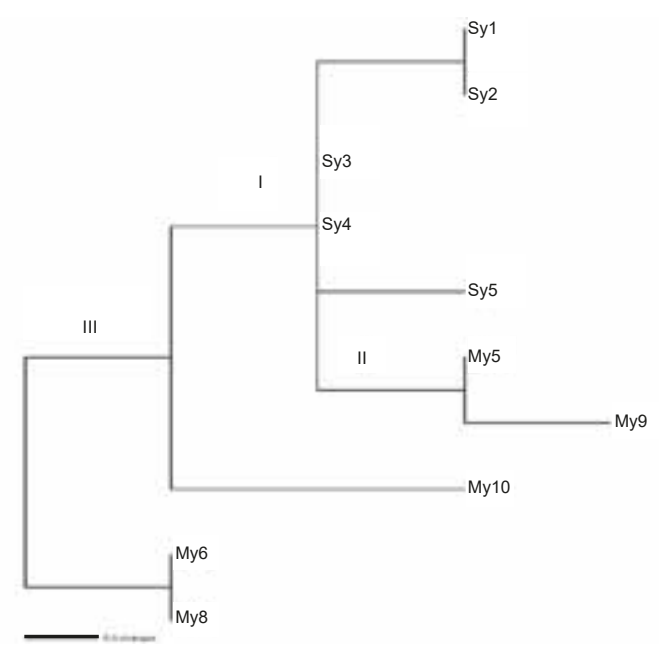

Figure 4. NJ dendrogram of $10 \mathrm{LAB}$ isolates based on RAPD data using the software PAUP version 4.0. . Isolates from Sylhet Division (Sy 1, Sy 2, Sy 3, Sy 4 and Sy 5); Isolates from Mymensingh Division (My 6, My7, My8, My9 and My 10). According to this analysis, Sy 1, Sy 2, Sy 3, Sy 4 and Sy 5were grouped together in NJ dendrograms. Sy1 and Sy 2 samples from Sylhet Division and My 6 and My 8 from Mymensingh Division showed close relationship and were placed together in NJ trees. 


\section{Discussion}

Lactic acid bacteria is one of the main components in dairy products fermentation. Yogurt is an abundant source of lactic acid bacteria. Lactobacillus species from yogurt samples were identified observing their morphological characteristics and different biochemical characteristics by Hoque et al. (2010). The result of different biochemical test ensured the presence of Lactobacillus in Dahi (Kavitha et al., 2016). These studies supported our lactic acid bacteria identification strategy. Good quality DNA contents observed in this experiment. This findings were quite similar to the work of Mustopa et al. (2018) and Sambrook et al. (1989). They observed good quality pure DNA contents at A260/280 were in the range of 1.8-2.0 and absorbance ratio at A260/230 were greater than 1.8 . The lower value than 1.8 indicates the protein contamination.

Molecular tools are very effective in discriminating bacterial species. According to Coeuret et al. (2003), molecular methods played an important role in isolation and identification of probiotic bacteria from traditional dairy products for industrial purposes. RAPD fingerprinting is more effective and sensitive than biochemical methods for evaluating genetic variation among the isolates. Genetic diversity of lactic acid bacteria were detected in this experiment by using RAPD marker. For discriminating lactic acid bacteria, RAPD were used in several experiments (Ruiz et al., 2008, Tafvizi et al., 2012). RAPD method was used for molecular classification and determination of the genetic relationship of Lactobacillus species (Dimitonova et al., 2008, Markiewicz et al., 2010). In several experiments, the of identification lactobacillus using RAPD analysis with the OPA primers were described. Different types of random primers like OPA 2 and OPA 5 (Weiss et al., 2005), OPA 2 (Hasslöf et al., 2013) were used in RAPD analysis. OPA 18 and OPA 5 showed better amplification in this study whereas OPA 2 and OPA 8 didn't produce satisfactory polymorphic bands. The polymorphism demonstrated in the RAPD pattern was not so high. This was may be due to low number of experimental data, time shortage and low number of primer trial. However, this study showed different degrees of variation in regional probiotic bacteria more or less.

The overall experiment carried landscape of genetic relativity of lactic acid bacteria on regional basis. Isolates from similar geography showed less genetic diversity. UPGMA (Unweighted pair group method of arithmetic mean) dendrogram and NJ (Neighbor- Joining) dendrogram were exhibited quite similar findings. Both dendrogram exhibited that genetic diversity of lactic acid bacteria depends on geographical location and sources. Geographical influence on lactic acid bacteria also observed in Kusdianawati et al. (2020) work. According to Abdollahniya et al. (2018), Lactobacillus isolates showed highest genetic similarity and grouping together that were collected from geographically less distant location and sources. In the present study, isolates from same cluster showed more genetic similarity.

\section{Conclusion}

Genetic diversity of lactic acid bacteria exhibited in regional yogurt samples. Ten lactic acid bacterial isolates were obtained from yogurt samples collected from different sweet meat shops of Sylhet and Mymensingh Divisions of Bangladesh. Isolates were analyzed using RAPD-PCR. 
On the basis of UPGMA and NJ dendrograms, isolates from distant locations showed more genetic variation than isolates from less distant regions. This study focuses on the genetic variation among lactic acid bacteria based on geographical location. As being used in the design of commercial starters, the lactic acid bacteria isolates characterized in this study might be used to help improve the safety of traditional yogurts through maintaining their original qualitative and sensorial characteristics. However, further investigations in this area may be able to give more information about genetic diversity in species and strains level.

\section{Acknowledgement}

The authors are grateful to the authority of National Agricultural Technology Program Phage II (NATP-2), Project Implementation Unit, Bangladesh Agricultural Research Council (BARC) for providing funding under Competitive Research Grant (CRG) by the World Bank.

\section{References}

Abdollahniya D., Hosseini S.M., Baghbaderani B.K., Mordadi A., Arabestani M.R. 2018. Identification of Lactobacillus Species Isolated From Traditional Dairy Products Using RAPD-PCR. Avicenna J. Clinical Microbiol. Inf. 5(2): 7-13.

Bintsis T. 2018. Lactic acid bacteria: their applications in foods. J. Bacteriol. Mycol. 6(2):89-94.

Chao S.H., Tomii Y., Watanabe K., Tsai Y.C. 2008. Diversity of lactic acid bacteria in fermented brines used to make stinky tofu. Intl J Food Microbiol 123: 134-141. Coeuret V., Dubernet S.,
Bernardeau M., Gueguen M., Vernoux J.P. 2003. Isolation, characterization and identification of lactobacilli focusing mainly on cheeses and other dairy products. EDP Sci. 83:269-306.

De S., Kaur G., Roy A., Dogra G. and Kaushik R. 2010. A Simple Method for the Efficient Isolation of Genomic DNA from Lactobacilli Isolated from Traditional Indian Fermented Milk (dahi).Indian J. Microbiol. 50(4):412-41.

Dimitonova S.P., Bakalov B.V., Aleksandrova-Georgieva R.N. and Danova S.T. 2008. Phenotypic and molecular identification of lactobacilli isolated from vaginal secretions. J. Microbiol. Immunol. Inf. 41(6): 469-477.

Hasslöf P., West C.E., Videhult F.K., Brandelius C, Stecksén-Blicks C. 2013. Early intervention with probiotic Lactobacillus paracasei F19 has no long-term effect on caries experience. Caries Res. 47(6):559-65.

Hoque M., Akter F., Hossain K., Rahman M., Billah M., Islam K. 2010. Isolation, identification and analysis of probiotic properties of Lactobacillus spp. from selective regional yoghurts. World J. Dairy and Food Sci. 5(1):39-46.

Kabir, S.M.L., Rahman S.S.M., Neogi S. and Rahman M. 2016. Isolation, identification, molecular

characterization and screening of probiotic activities of Lactobacillus species from poultry sources at live bird markets in Mymensingh, Bangladesh. Asian Australas. J. Biosci. Biotechnol. 1:54-65.

Kaur J., Sharma, A., Lee S. and Park Y. S. 2016. RAPD typing of Lactobacillus 
brevis isolated from various food products from Korea. Food sci. biotechnol. 25(6):1651-1655.

Kavitha, P., Sindhuja D. and Banumathi M. 2016. Isolation and Biochemical Characterization of Lactobacillus species Isolated from Dahi. Int. J. Curr. Microbiol. App. Sci. 5(4): 1042-1049.

Kusdianawati, Mustopa A.Z., Fatimah, Bugi R. and Budiart B.R. 2020. Genetic diversity of lactic acid bacteria isolated from Sumbawa horse milk, Indonesia. Biodiversitas 21:3225-3233. Lilly D.M. and Stillwell R.H. 1965. Probiotics: Growth promoting factors produced by microorganisms. Sci. 147: 747-748.

Markiewicz L.H., Biedrzycka E., Wasilewska E.and \& Bielecka M. 2010. Rapid molecular identification and characteristics of Lactobacillus strains. Folia Microbiol. 55:481-488.

Mayer H.M, Weiss A., Lettner H.P. and Kramer W. 2005. Molecular Methods Used for the Identification of Potentially Probiotic Lactobacillus reuteri Strains. Food Technol. Biotechnol. 43 (3):295-300.

Mustopa A.Z, Puspitasari I.F., Fatimah, Triratna L. and Kartina G. 2018. Genetic diversity of mastitis cow's milk bacteria based on RAPD-PCR. Biodiversitas 19(5): 1714-1721.

Nei and M. 1972 . Genetic distance between populations. Am. Nat. 106 (949): 283-292.

Nero L.A., De Mattos M. R., De Aguiar Ferreira Barros M., Ortolani M.B.T., Beloti V., De Melo Franco B. D. G. 2008. Listeria monocytogenes and Salmonella spp. in Raw Milk Produced in Brazil: Occurrence and Interference of Indigenous Microbiota in their Isolation and Development. Zoonoses Public Health 55(6): 299- 305.

Ruiz P., Izquierdo P.M., Seseña S., Palop M.L. 2008. Intraspecific genetic diversity of lactic acid bacteria from malolactic fermentation of Cencibel wines as derived from combined analysis of RAPD-PCR and PFGE patterns. Food Microbiol. 25(7):942-948.

Samarzija D., Sikora S., Redzepovic S., Antunac N. and Havranek J. 2002. Application of RAPD analysis for identification of Lactococcus lactis subsp. Cremoris strains isolated from artisanal cultures. Microbiol. Res. 157:13-17.

Sambrook J., Fritsch E.F., Maniatis T. 1989. Molecular Cloning a Laboratory Manual, 2nd Ed. Cold Spring Harbour Laboratory Press, New York.

Tafvizi F. and Tajabadi E. M. 2012. Detection of genetic diversity and classification of Lactobacillus species isolated from Iranian traditional dairy products by RAPD fingerprinting and POPGENE analysis. Ann. Biol. Res. 3:4904-4911.

Wang H., Livingston K.A., Fox C.S., Meigs J.B. and Jacques P.F. 2013. Yogurt consumption is associated with better diet quality and metabolic profile in American men and women. Nutr. Res. 33(1):1826.

Weiss A., Lettner H.P., Kramer W., Mayer H. and Kneifel W. 2005. Molecular Methods Used for the Identification of Potentially Probiotic Lactobacillus reuteri Strains. Food Tech. Biotechnol.43:295-300. 